\title{
ENZYMIC HYDROLYSIS OF COMMON CELLULOSIC WASTES BY CELLULASE
}

\author{
SURINDER DHAWAN AND J. K. GUPTA \\ Department of Microbiology, Panjab University, Chandigarh-160014, India
}

(Received March 2, 1977)

\begin{abstract}
Under optimum conditions, the unconcentrated filtrate of Trichoderma viride QM 9414 showed a considerable cellulolytic activity against newspaper yellow and cardboard which were preferentially attacked by the enzyme. The percentage conversion was 46.6 and 42.2 in $24 \mathrm{hr}$, respectively. The alkali treatment resulted in increased degradation of sugar cane bagasse from 7 to $48.1 \%$ (24-hr treatment with enzyme) and to $70 \%$ (48-hr treatment with enzyme). The bagasse hydrolyzate was found by chromatography to contain mainly glucose, xylose, arabinose, cellobiose, and unidentified saccharides. The hydrolyzate, when enriched with urea and yeast extract, supported good growth of Saccharomyces cerevisiae, Candida tropicalis, Pseudomonas aeruginosa, Escherichia coli, Lactobacillus casei, and Rhizobium meliloti.
\end{abstract}

Cellulose is the most abundant organic compound in wastes from forest products, agriculture, fruits, and vegetables. This cellulose could be converted into simple sugars by enzymic degradation. These sugars can then be used as microbial substrates to produce a variety of fermentation chemicals (alcohols, solvents, etc.) or single cell protein, or they can serve as the base for the manufacture of organic chemicals. Recently increasing interest has been in the problem of finding new food sources for our expanding population by growing microorganisms on such materials as petroleum and cellulosic wastes.

The economics of the conversion of cellulose into sugars depends on two factors. Firstly a supply of enzyme of sufficient activity, stability, and economy is required. Secondly the cellulosic materials must be treated physically or chemically so that suspensions with high solid ratios are obtained and interfering components (like lignin, etc.) are removed to expose the natural cellulose.

In the present study, enzymic saccharification of a variety of waste cellulosic materials was studied and pretreatment to increase the availability of the cellulose in agricultural wastes with alkali was evaluated. The hydrolyzate obtained was used to grow a number of bacteria and yeasts. 


\section{MATERIALS AND METHODS}

Organism and enzyme preparation. After a survey of different cellulolytic fungi obtained from various sources, Trichoderma viride 9414 was found to produce maximum cellulase $\left(C_{x}\right)$, when grown under conditions described earlier $(1)$. This organism obtained from Dr. Mary Mandels, U.S. Army Natick Laboratories, Massachusetts, U.S., was grown for cellulase production on Reese and Mandels medium (2), which had the following composition (per liter): $\mathrm{KH}_{2} \mathrm{PO}_{4}, 2.0 \mathrm{~g}$; $\left(\mathrm{NH}_{4}\right)_{2} \mathrm{SO}_{4}, 1.4 \mathrm{~g} ;\left(\mathrm{NH}_{2}\right)_{2} \mathrm{CO}, 0.3 \mathrm{~g} ; \mathrm{MgSO}_{4} \cdot 7 \mathrm{H}_{2} \mathrm{O}, 0.3 \mathrm{~g} ; \mathrm{CaCl}_{2}, 0.3 \mathrm{~g} ; \mathrm{FeSO}_{4}$. $7 \mathrm{H}_{2} \mathrm{O}, 0.5 \mathrm{mg} ; \mathrm{MnSO}_{4} \cdot \mathrm{H}_{2} \mathrm{O}, 1.6 \mathrm{mg} ; \mathrm{ZnCl}_{2}, 1.7 \mathrm{mg} ; \mathrm{CoCl}_{2}, 2.0 \mathrm{mg}$, and proteose peptone, $1.0 \mathrm{~g}$. The $\mathrm{pH}$ of the medium was adjusted to 5.3 with $\mathrm{NaOH}$. Avicel was used as the cellulose source and added to the flasks individually at $1 \%$ concentration. The enzyme preparation obtained was the extracellular cultural fluid, straw yellow in colour with 80 units of activity per $\mathrm{ml}$. (One unit of enzyme activity was taken as that amount of enzyme which gave $4 \mathrm{mg}$ of reducing sugars from carboxymethylcellulose (CMC)-7MT as substrate in $1 \mathrm{hr}$ at $50^{\circ}$ ). The assay mixture contained $4.5 \mathrm{ml}$ of $1.1 \%$ CMC-7MT in citrate buffer $(0.055 \mathrm{M}$, $\mathrm{pH} 5.0$ ) and $0.1 \mathrm{ml}$ of diluted enzyme preparation, made to a final volume of $5.0 \mathrm{ml}$ with citrate buffer.

Cellulosic materials. Avicel RC-581 cellulose used as the carbon source in enzyme preparations was obtained from FMC corporation, American Viscose Division, Marcus Hook, U.S.A. Newspaper (yellow and white), cardboard (packing material), and filter paper (Whatman \#41) were used after cutting them into small pieces. Wheat straw, maize straw, bagasse (sugar cane), rice husk, and wood powder were initially dried in the oven at $70^{\circ}$ for $36 \mathrm{hr}$, ground in an electric grinder, and sieved through a 40-mesh sieve.

Treatment of raw materials with alkali (3). Eight grams of the cellulosic materials like wheat straw, maize straw, sugar cane bagasse, rice husk, and wood powder were boiled in $240 \mathrm{ml}$ of $1 \% \mathrm{NaOH}$ for $1 \mathrm{hr}$. The materials were extensively washed initially with tap water and number of times with distilled water until the supernatant was free of alkali checked by a litmus paper. The materials thus obtained were oven-dried at $40^{\circ}$ and pulverized into a fine powder.

Estimation of breakdown of celluloses. This involved the estimation of reducing sugars formed by the action of unconcentrated enzyme filtrate on the cellulosic material (4). The $\mathrm{pH}$ of the enzyme filtrate was adjusted to 5.0 and the enzyme contained $0.05 \%$ merthiolate as a preservative. The reaction mixture contained enzyme filtrate ( $80 \mathrm{units} / \mathrm{ml}), 4.0 \mathrm{ml}$; cellulosic material, $300 \mathrm{mg}$; citrate buffer $(0.055 \mathrm{M}, \mathrm{pH} 5.0), 3.0 \mathrm{ml}$, and the reaction was performed in $30-\mathrm{ml}$ test tubes at $40^{\circ}$ for $24 \mathrm{hr}$. After the incubation period, the contents were filtered. An aliquot (volume upto $1 \mathrm{ml}$ ) containing reducing sugars equivalent to between 0.1 and $1.0 \mathrm{mg}$ of glucose was added to $3 \mathrm{ml}$ of the reagent $(5,6)$ containing $1 \%$ of 3,5-dinitrosalicyclic acid, $0.2 \%$ of phenol, $0.05 \%$ of $\mathrm{Na}_{2} \mathrm{SO}_{3}, 1 \%$ of $\mathrm{NaOH}$, and $20 \%$ of Rochelle salt. The solution was kept in boiling water for $15 \mathrm{~min}$, then 
diluted with water, and the optical density read at $550 \mathrm{~nm}$. D-Glucose was used for preparing the standard curve and the total reducing sugars liberated by cellulolysis in $7.0 \mathrm{ml}$ of the reaction mixture were extrapolated, using this curve.

Identification of the products of sugar cane bagasse hydrolyzate. The reducing sugars formed by the enzymic breakdown of the alkali-treated bagasse were identified by the one-dimensional ascending paper chromatographic technique. The hydrolyzate obtained after 48-hr incubation of sugar cane bagasse with enzyme was spotted with glucose, xylose, arabinose, and cellobiose, which acted as markers. These markers were also used as an internal standard to further confirm their presence in the hydrolyzate. The solvent system used was butanol: pyridine: water $=$ $6: 4: 3(7)$. Complete separation of components took place in $48 \mathrm{hr}$. The paper was air-dried and sprayed with $0.5 \%$ benzidine solution $(0.5 \mathrm{~g}$ benzidine in $20.0 \mathrm{ml}$ glacial acetic acid and $80.0 \mathrm{ml}$ of absolute ethanol) (8). The chromatogram was dried at room temperature and heated in an oven at $100^{\circ}$ for $10 \mathrm{~min}$. Benzidine distinctly distinguishes pentoses from hexoses by producing a chocolate colour with the former and brown with the latter.

Growth of yeasts and bacteria on bagasse hydrolyzate. When $300 \mathrm{mg}$ of alkalitreated bagasse was incubated with $7 \mathrm{ml}$ of the enzyme-buffer mixture for $24 \mathrm{hr}$, $2.07 \%$ of reducing sugars was formed in the hydrolyzate. The degradation was done using a larger volume of enzyme and substrate. The hydrolyzate, which had about the same total sugar content, was enriched with urea $(0.03 \%)$ and yeast extract $(0.01 \%)$. The $\mathrm{pH}$ was adjusted to 5.0 for yeasts $(9)$ and 7.0 for bacteria. Four $\mathrm{ml}$ of the enriched hydrolyzate was dispensed into small test tubes $(1 \times 10 \mathrm{~cm})$, sterilized, and inoculated with Saccharomyces cerevisiae, Candida tropicalis, Torulopsis yeast, Pseudomonas aeruginosa, Escherichia coli, Lactobacillus casei, and Rhizobium meliloti. Yeasts and bacteria were incubated at $30^{\circ}$ and $37^{\circ}$, respectively, for $96 \mathrm{hr}$ under static condition. For the sake of comparison, controls were made with these organisms grown on a synthetic medium containing glucose (equivalent to reducing sugars in bagasse hydrolyzate), urea $(0.03 \%)$, and yeast extract $(0.01 \%)$. Visual observations of growth were recorded every $24 \mathrm{hr}$.

\section{RESULTS AND DISCUSSION}

\section{Enzymic degradation of common cellulosic materials}

Maximum degradation was obtained in the case of yellow newspaper and cardboard (Table 1), followed by filter paper and white newspaper. Rice husk was attacked least, only to the extent of $2 \%$. The effect of enzyme on cardboard is easily noticed visually (Fig. 1). The results obtained here are in agreement with earlier reported work $(4,10,11)$. As much as $46.6 \%$ of the yellow newspaper was degraded into sugars in $24 \mathrm{hr}$ which showed the highly cellulolytic nature of the enzyme preparation. The reducing sugars formed are known to correspond approximately to the quantity of cellulosic materials hydrolyzed $(4,12)$. 
Table 1. Enzymic degradation of common cellulosic materials.

\begin{tabular}{lcc}
\hline Material & Total sugars formed $(\mathrm{mg})$ & Percent conversion* \\
\hline Newspaper-yellow & 140.0 & 46.6 \\
Cardboard & 126.7 & 42.2 \\
Filter paper & 70.0 & 23.3 \\
Newspaper-white & 67.4 & 22.5 \\
Maize straw & 48.3 & 16.1 \\
Wheat straw & 38.9 & 12.9 \\
Cotton (non-absorbent) & 30.1 & 10.0 \\
Cotton (absorbent) & 26.9 & 8.9 \\
Wood powder & 21.4 & 7.2 \\
Sugar cane bagasse & 21.0 & 7.0 \\
Rice husk & 6.0 & 2.0 \\
\hline
\end{tabular}

Reaction mixture: Enzyme filtrate ( 80 units $/ \mathrm{ml}), 4.0 \mathrm{ml}$; cellulosic material, $300 \mathrm{mg}$; citrate buffer $(0.055 \mathrm{M}, \mathrm{pH} 5.0), 3.0 \mathrm{ml}$; temp. $40^{\circ}$; incubation period, $24 \mathrm{hr}$.

* Conversion $(\%)=\frac{\text { Total sugars formed }}{\text { Weight of substrate }} \times 100$

Enzymic degradation of alkali-treated materials.

Four cellulosic agricultural materials, viz., sugar cane bagasse, wheat straw, maize straw and rice husk were subjected to alkali treatment and it was found that the treatment enhanced the enzymic degradation of these materials. In $24 \mathrm{hr}$, these materials were degraded up to $48.1,40.8,37.9$, and $6.9 \%$, respectively (Table 2). There was 2.3- to 6.8-fold increase in sugar formation as a result of alkali treatment of these materials when we compare these results with Table 1.

The effect was distinct in the case of sugar cane bagasse where the sugar formation increased from 7.0 to $48.1 \%$. Increased sugar formation by alkali treatment of bagasse $(4,11,13-15)$ and woody wastes (3) has been reported earlier.

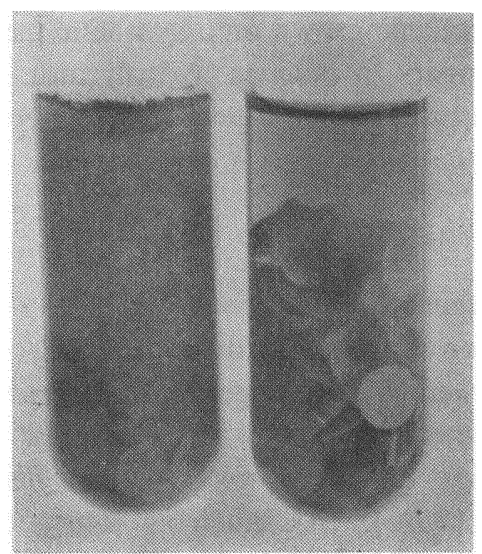

(A)
(B)

Fig. 1. Degradation of cardboard pieces by cellulase.

A, incubated with enzyme filtrate for $24 \mathrm{hr}$; B, incubated with citrate buffer only for $24 \mathrm{hr}$. 
Table 2. Enzymic degradation of alkali-treated agricultural wastes.

\begin{tabular}{lcc}
\hline Material & Total sugars formed $(\mathrm{mg})$ & Percent conversion* \\
\hline Sugar cane bagasse & 144.4 & 48.1 \\
Wheat straw & 122.5 & 40.8 \\
Maize straw & 113.7 & 37.9 \\
Rice husk & 20.9 & 6.9 \\
\hline
\end{tabular}

Reaction mixture: Enzyme filtrate ( 80 units $/ \mathrm{ml}), 4.0 \mathrm{ml}$; alkali-treated material, $300 \mathrm{mg}$; citrate buffer $(0.055 \mathrm{M}, \mathrm{pH} 5.0), 3.0 \mathrm{ml}$; temp. $40^{\circ}$; incubation period $24 \mathrm{hr}$.

* Conversion $(\%)=\frac{\text { Total sugars formed }}{\text { Weight of substrate }} \times 100$

Although the exact mechanism of action of alkali is not clear (16) it definitely brings about some delignification. It is also known that lignin acts as a barrier between the enzyme and natural cellulosic substrate.

\section{Identification of the products of bagasse hydrolyzate}

Sugar cane bagasse, a common agricultural waste, is a complex natural material consisting of cellulose, hemicellulose, and other constituents. The hydrolyzate obtained after its enzymic hydrolysis was looked for various pentoses

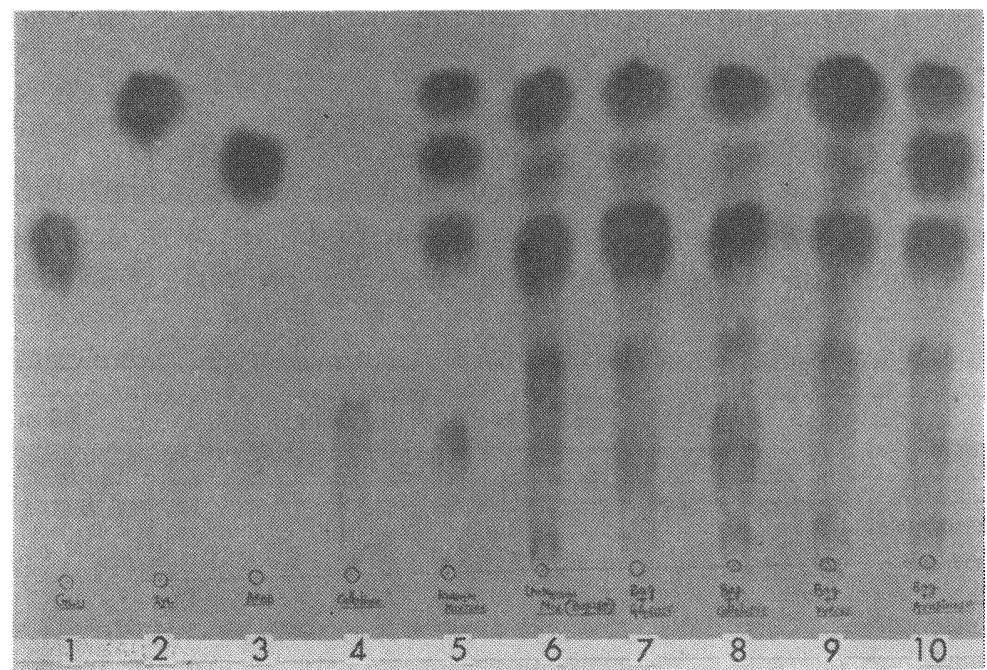

Fig. 2. Separation of components of alkali-treated bagasse hydrolyzate in the presence of glucose, xylose, arabinose, and cellobiose as internal standards by ascending chromatography using butanol: pyridine: water $=6: 4: 3$.

1-4, glucose, xylose, arabinose, and cellobiose (markers); 5, markers spotted together as known mixture; 6, alkali-treated bagasse hydrolyzate (unknown mixture); 7, alkalitreated bagasse hydrolyzate + glucose as internal standard; 8 , alkali-treated bagasse hydrolyzate + cellobiose as internal standard; 9, alkali-treated bagasse hydrolyzate + xylose as internal standard; 10 , alkali-treated bagasse hydrolyzate + arabinose as internal standard. 
and hexoses. The sugars formed were separated by the ascending paper chromatography. The separation of the spots in shown is Fig. 2. The paper chromatography of the bagasse hydrolyzate revealed the presence of mainly glucose, xylose, arabinose, and some cellobiose. Further confirmation of the presence of these sugars in the hydrolyzate was obtained by using the markers as internal standards. It was also observed from the intensity of these spots that the concentration of arabinose and cellobiose was low compared to other sugars. The presence of a small quantity of other unknown saccharides was also noticed. ToYAMA et al. (14) reported the formation of cellobiose, glucose, and xylose from bagasse, and ANDREN et al. (17) from other cellulosic wastes. The presence of very little cellobiose in bagasse hydrolyzate in our study is due to an active $\beta$-glycosidase which was probably present in the filtrate. However, cellobiose as the main product of cellulolysis has also been reported $(18,19)$. Xylose and arabinose were present in the hydrolyzate indicating the production of hemicellulases along with cellulase, a fact noticed earlier by GASCOIGNE and GASCOIGNE (20), and by BuCHT and ERIKSSON (21). However, ToDA et al. $(22,23)$ reported enzyme preparation of $T$. viride showing hemicellulase (xylanase) and cellulase (CMCase) activities which remained unchanged regardless of separation method (electrophoresis, adsorption chromatography). They suggested that cellulase and xylanase activities were due to a single enzyme protein and the two substrates (CMC and xylan) compete for the same active site.

Growth of yeasts and bacteria on alkali-treated bagasse hydrolyzate

In order to know if the sugar in the hydrolyzate would support the growth of common microorganisms, the hydrolyzate was enriched with urea and yeast extract, and inoculated with few species of yeasts and bacteria. For comparison

Table 3. Growth of yeasts and bacteria on alkali-treated bagasse hydrolyzate.

\begin{tabular}{|c|c|c|c|c|c|c|c|c|}
\hline \multirow{2}{*}{ Organism } & \multicolumn{2}{|c|}{$24 \mathrm{hr}$} & \multicolumn{2}{|c|}{$48 \mathrm{hr}$} & \multicolumn{2}{|c|}{$72 \mathrm{hr}$} & \multicolumn{2}{|c|}{$96 \mathrm{hr}$} \\
\hline & $\mathrm{H}$ & $\mathrm{S}$ & $\mathrm{H}$ & $\mathrm{S}$ & $\mathbf{H}$ & $\mathrm{S}$ & $\mathrm{H}$ & $\mathrm{S}$ \\
\hline Saccharomyce & & & & & & & & \\
\hline cerevisiae & + & + & ++ & ++ & $+t+t$ & ++++ & $+++t$ & $++t+$ \\
\hline Candida & & & & & & & & \\
\hline tropicalis & + & + & ++ & ++ & $++t+$ & +++ & $++t+$ & $+t+t$ \\
\hline $\begin{array}{l}\text { Torulopsis } \\
\text { yeast }\end{array}$ & \pm & - & + & - & + & \pm & ++ & \pm \\
\hline $\begin{array}{r}\text { Pseudomonas } \\
\text { aeruginosa }\end{array}$ & + & + & ++ & ++ & $+t+$ & $++t$ & +++ & +++ \\
\hline $\begin{array}{l}\text { Escherichia } \\
\quad \text { coli } \\
\text { Lactobacillus }\end{array}$ & + & + & ++ & ++ & $+t+$ & +++ & $+t+t$ & $+t+$ \\
\hline $\begin{array}{l}\text { casei } \\
\text { Rhizobium }\end{array}$ & + & \pm & ++ & + & +++ & + & ++++ & + \\
\hline meliloti & + & \pm & ++ & + & $+t+$ & ++ & $++t$ & $+t+$ \\
\hline
\end{tabular}

H, Bagasse hydrolyzate; S, Synthetic medium. 
the organisms were also inoculated into a synthetic medium. The data obtained by visual observation are presented in Table 3 .

It was clearly established that Lactobacillus casei, Rhizobium meliloti, and Torulopsis yeast (unidentified) grew better in the hydrolyzate medium than in the synthetic medium. This could be due to the presence of additional nutrients (e.g., phosphates, nitrogen, and other metallic ions) which came from the crude enzyme into the hydrolyzate or unknown growth stimulator. The fact that enriched hydrolyzate is a good source of nutrients is further proved from growth of Saccharomyces cerevisiae, Pseudomonas aeruginosa, Candida tropicalis, and Escherichia coli.

The authors are grateful to Prof. D. V. Vadehra, Head, Microbiology Department, Panjab University, for providing laboratory facilities for this work.

\section{REFERENCES}

1) J. K. Gupta, N. B. Das, and Y. P. Gupta, Agric. Biol. Chem. (Tokyo), 36, 1961 (1972).

2) E. T. Reese and M. Mandels, Methods Carbohydr. Chem., 31, 139 (1963).

3) N. Toyama and K. Ogawa, Proc. IVth Int. Ferment. Symp., Ferment. Technol. Today, 743 (1972).

4) J. K. Gupta, Y. P. Gupta, and N. B. Das, Agric. Biol. Chem. (Tokyo), 37, 2657 (1973).

5) J. B. Summer and G. F. Somers, Laboratory Experiments in Biological Chemistry, Academic Press, New York (1944).

6) G. L. Miller, Anal. Chem., 31, 426 (1959).

7) M. J. Crumpton, Biochem. J., 72, 479 (1959).

8) R. H. Horrocks, Nature (London), 164, 444 (1944).

9) M. Mandels and J. Weber, Adv. Chem. Ser., 95, 391 (1969).

10) M. MANDels and E. T. ReESE, Dev. Indust. Microbiol., 5, 5 (1964).

11) R. P. Ghildyal, Master of Science thesis submitted in Chemical Engineering Department of I. I. T., New Delhi (1970).

12) A. R. A. Akmada, J. Margaret, and B. H. Howard, Biochem. J., 89, 268 (1963).

13) S. Toyama and M. YASUi, Ryukyu Daigaku Nogakubu Gakujutsu Hokoku, 16, 147 (1969).

14) S. Toyama, K. Migazato, and H. KinJo, Ryukyu Daigaku Nogakubu Gakujutsu Hokoku, 19, 279 (1972).

15) I. J. Babbar, Chem. Age India, 26, 505 (1975).

16) W. J. Clawson and W. N. Garrett, Calif. Agric., 24, 13 (1970).

17) R. K. Andren, M. H. Mandels, and J. E. Medeiros, Appl. Polym. Symp., 28, 205 (1975).

18) W. O. Storvick and K. W. King, J. Biol. Chem., 235, 303 (1960).

19) Y. W. Han and V. R. Srinivasan, Appl. Microbiol., 16, 1140 (1968).

20) J. A. Gascoigne and M. Gascoigne, Biological Degradation of Cellulose, Butterworths, London (1960).

21) B. Bucht and K. Eriksson, Arch. Biochem. Biophys., 124, 135 (1968).

22) S. Toda, H. Suzuki, and K. Nisizawa, Hakko Kogaku Zasshi, 48, 580 (1970).

23) S. Toda, H. Suzuki, and K. Nisizawa, Hakko Kogaku Zasshi, 49, 499 (1971). 